[ ensaio ]

\title{
Visionarismo satânico no poema em prosa de Cruz e Sousa: trabalho poético e marginalidade
}

\section{Simone Rossinetti Rufinoni}

Resumo A partir da abordagem de alguns poemas em prosa de Cruz e Sousa, a autora aponta os dramas e os antagonismos vividos por um poeta negro, atormentado pelo preconceito num país escravista. "Assinalado" pelo trabalho poético, Cruz e Sousa encarna satanicamente o discurso e os valores da época, como um visionário que contempla sua inevitável condição.

\begin{abstract}
Analysing some of the prose poems by Cruz e Sousa, the author makes a point of the antagonisms and dramatic situations experienced by a black writer harassed by the prejudice in a slavocrat country. "Signalized" by the poetic art, the poet incorporates with a devilish disposition the discourse and the values of a time like a visionary who watches his inevitable condition.
\end{abstract}

Palavras-chave poemas satanismo país escravista Keywords poems satanism-slavocrat country 


\section{Dandismo e morte: o heroísmo do excluído}

A recepção crítica contemporânea à obra de Cruz e Sousa foi quase unânime em apontar o drama do poeta como característico de seu desejo de ascensão social, como forma de defesa face às acusações de seus contemporâneos contra sua obra e o simbolismo; ou seja, uma espécie de torre de marfim onde o poeta renegado se refugiara do mundo e de suas incompreensões. O tema romântico do poeta isolado, que se afasta da sua realidade para criar, é aspecto que ajuda a compreender a obra do poeta apenas se acrescentado a outros; (...) esse tema sofre igualmente uma transformação profunda, porque se ouve no fundo o grito de uma raça oprimida"। A aparente recusa frente à realidade, expressa pelo culto à personalidade, evidencia a defesa do excluído. Renegado pela sua cor, o poeta funde a crença romântica do artista eleito à noção simbolista do poeta vidente, conferindo-lhe tonalidades personalíssimas. No fundo das atitudes de diferenciação do artista, insere-se o clamor daquele que carrega consigo o exílio na pele.

O dandismo revela-se meio de escape frente à realidade opressora. Em tal fuga, o sujeito aproxima-se do satanismo e do mal apreendidos como formas de se opor ao mundo. Sua atitude de constante negação desvenda um fundo transgressor, rebeldia que se dá pelo culto do refinamento. ${ }^{2}$

Este poeta humilhado e incompreendido clama para que Satã o auxilie no seu percurso de descobrimento, de mergulho no inefável; aquele que foi expulso saberá orientar aquele que foi excluído. Os poemas em prosa que indicam mais fortemente a valorização do eu como o assinalado são marcados por veemente protesto satânico; não há transcendência possível no reino da matéria triste e soberana. O artista deve fechar-se ao mundo para conseguir transfigurá-lo com maior agudez:

Para resistir aos perturbadores ululos do mundo fecha-te à chave astral com a al-

1 BASTIDE, Roger. "Ouatro estudos sobre Cruz e Sousa" In: COUTINHO, Afrânio (org. ). Cruz e Sousa Rio de Janeiro: Civilização Brasileira, 1979, p. 173.

2 LEVIN, Orna Messer. Figurações do dândi. São Paulo: Ed da Unicamp, 1996, p. 40-9. 
ma, essa esfera celeste, dentro das muralhas de ouro do Castelo do Sonho, lá muito em cima, lá no alto da torre azul mais alta dentre as altas torres coroadas d'estrelas. ${ }^{3}$

O trecho opera uma polarização entre o mundo real marcado pelos "perturbadores ululos" e o universo interior do artista, a sonhar com o idealismo da arte. Os traços de comportamento recluso da obra e vida do poeta, comumente associados a um desejo aristocratizante, apontam para uma espécie de "dandismo baudelairiano"4 que não se resume à aparência externa, mas define-se como atitude introspectiva, aspecto diferenciador do indivíduo que se espelha tanto na sua aparência quanto na sua obra. E este poeta atormentado pelo preconceito de um país escravista procura hastear seu talento como compensação frente à realidade sufocante do poeta negro. Dos reais tormentos, o poeta perfaz uma dor metafísica que inclui e entrelaça a do poeta negro, a da criação poética e uma outra que implica a percepção de um mundo esfacelado, sem deuses.

A solidão do artista surge como elemento necessário à elaboração da forma abaladora, capaz de transfigurar realidades e lançar sua ironia ao mundo. O poema em prosa "Condenado à morte" traça a paixão do poeta, no sentido de seu percurso de artista-mártir, do "doloroso Estético" identificado em terceira pessoa e duplo do poe-

3 SOUSA, João da Cruz e. "Iniciado" In: Obra completa (Evocações). São Paulo: Aguilar, 1995, p.523.

4 "O conceito de dandismo em Baudelaire está longe de corresponder a qualquer atitude meramente exterior. É uma realidade das mais entranhadas nas profundezas do ser" HADDAD, lamil A. "Baudelaire e o Brasil" (prefácio). In: BAUDELAIRE, Charles. Flores do mal. $2^{a}$ ed. Sāo Paulo: Difusão Européia do Livro, 1964, p. 42 sobre o "dandismo baudelariano" ver também: BAUDELAIRE, Charles. "Le peintre de la vie moderne" In: Oeuvres complètes. Genebra: Cercle du Bibliophile, s.d., v. 3. p. 84-5: "Qu'est-ce donc que cette passion (...)? C'est avant tout le besoin ardent de se faire une originalité, contenu dans les limites extérieures des convenances. C'est une espèce de culte de soi-même qui peut survivre à la recherche du bonheur (...) tous sont des représentants de ce qu'il y a de meilleur dans l'orgueil humain, de ce besoin, trop rare chez ceux d'aujourd'hui, de combattre et de détruire la trivialití." Em tradução literal: "O que é então esta paixão? É antes de tudo o desejo ardente de se fazer uma originalidade, contida nos limites exteriores das conveniências. É uma espécie de culto de si mesmo que pode sobreviver a uma procura da felicidade (...) são todos representantes daquilo que há de melhor no orgulho humano, desta necessidade demasiado rara nos homens de hoje, de combater e de destruir a trivialidade' 
ta. O tema deste texto é a relação do poeta com o mundo: seus embates e a suposta vitória da Arte inevitavelmente atada à condenação do poeta à morte:

Ele já estivera em contatos com o Mundo, sentindo-o, respirando o mesmo ar, chocando-se com as paixões mais vorazes, com os coraçōes mais gelados, roídos pelo cancro alastrante de um tédio doentio, de um nirvanismo agudo, de um nifil eslavo... ${ }^{5}$

A caracterização do "doloroso Estético" isto é, do artista, oscila entre uma percepção fundada na positividade - o poeta é o único ser verdadeiramente livre e o vidente capaz de escandalizar o mundo - e na negatividade - apesar da sobrevivência da arte, o poeta sabe-se condenado à morte, morto em vida. Como exemplo do idealismo da primeira posição, tem-se o trecho:

Isolado do Mundo, no exílio da Concentração, solitário, na tristeza majestosa de um belo deus esquecido, as outras forças múltiplas que agem na Terra, na luta desenfreada de cada dia, que equilibram as sociedades, que regem a massa vã dos princípios, que dão ritmo à onda eterna do movimento e entram na vasta elaboração da cultura das raças, sentiram-se hostilizados diante da sua intuitiva percuciência de vidente, da sua ironia gelada de asceta, do seu desdém soberano de apóstolo, da sua Fé indestrutível, serena de missionário, de extraordinário levita sombrio de um culto estranho, que leva aos lábios, em extremo, o Cálix místico da comunhão suprema da Espiritualidade e da Forma. ${ }^{6}$

Como uma parábola, o poeta é aquele que tudo viu (sete dos parágrafos iniciam-se pelos verbos ver e observar: "ele viu" "ele observara tudo" "vira tudo isso"..), observou o cortejo das misérias humanas; a fascinação da mulher, as venturas e as ambições. Mas recusou as sensações fáceis, as ilusões juvenis e dedicou-se "aos martirizantes cilícios das Idéias" Após tal trecho, que evidencia a crença na arte como instrumento capaz de enfrentar a realidade, o poeta contempla a morte:

E então, o doloroso Estético, soberbo e sublime na sua solidão e no seu silêncio. vagueou - afastado do foco real, positivo da Vida - sem existir de fato, como um simples conde-

5 SOUSA, João da Cruz e, op. cit., "Condenado à morte" p. 542.

6 Idem, p. 544 
nado à Morte, errante fantasma na sombra de sepulcros, misteriosamente vibrado por um grande Sonho doloroso ritmado nas longas, monótonas e amargurantes melancolias do Mar, para sempre gemendo e sonhando, noturnamente, velhas lendas bárbaras. ${ }^{7}$

A reivindicação do poeta assinalado não é, portanto, apenas sublimação do complexo de inferioridade, como a crítica muitas vezes sugeriu, mas antes marca subjetiva, viés original de oposição e revolta contra a sociedade e as convenções. Posicionando-se à margem da sociedade, o poeta pode penetrar mais profundamente os fundamentos da estrutura social. Cria um mundo à parte que pode implodir o que the é externo: o mundo de fora comparece transfigurado pelo inquieto mundo interior.

Assim, esse dândi é a encarnação possível do herói na modernidade. Walter Benjamin, em análise sobre o mesmo tema em Baudelaire, aponta que na modernidade o herói só pode surgir como dândi. O ócio e a recusa da mundanidade são atitudes que expressam a modernidade do dândi, no sentido da recusa intransigente, mesmo que fadada ao fracasso

A modernidade se revela como sua fatalidade (do herói). Nela o herói não cabe; ela não tem emprego algum para esse tipo. Amarra-o para sempre a um porto seguro; abandona-o a uma eterna ociosidade. Nessa derradeira encarnação o herói aparece como dândi. ${ }^{8}$

O dândi é um estetizador. Seu trabalho é o de viver de forma tão meticulosa e individualista quanto a criação artística o exige. Ele conhece o mundo segundo suas formas, o que significa observá-lo enquanto objeto e portanto vê-lo desprovido de qualquer sentido transcendente. No seu suposto aristocratismo insere-se o repúdio à ordem social, às mesquinharias dos literatos, às imagens positivas do processo civilizatório então vigente ${ }^{9} \mathrm{e}$ à vulgaridade da multidão. Em Cruz e Sousa, essa multidão

7 ldem.

8 BENIAMIN, Walter. In: Charles Baudelaire, um lírico no auge do capitalismo. $3^{a}$ ed. São Paulo: Brasiliense, 1994, v. 3, p. 93.

9 No caso de Cruz e Sousa, as imagens positivas do Brasil da República são contrapostas à negatividade de suas fantasmagorias 
que o dândi observa possui dois aspectos; de um lado significa a mediocridade da maioria, o senso comum, as opiniões estabelecidas que atacavam sua pessoa, sua obra e o grupo dos Novos a que pertencia e, de outro, encarna o contingente de negros dos quais deseja diferenciar-se. Quanto ao escravo, contudo, num movimento de atração e repulsão, o poeta não deixa de lhe ser solidário à sua maneira. Sob esse aspecto é exemplar a leitura do poema em prosa "Asco e dor"

A aguda estetização do mundo é a do sujeito que quer recriar o universo. Trata-se da criação intelectual de um mundo à parte e de uma existência heróica, artificialismo que traz a arte para a vida e questiona os parâmetros da representação. Os limites entre esteticismo e experiência confundem-se a ponto da vida "representar" a arte e a arte "apresentar" a vida. O procedimento de estetização contínua expõe o trabalho artístico e pode questionar a utilidade da arte; substitui a representação idealizada da sociedade como meio de distinção e reconhecimento social pelo trabalho de desidentificação promovido pelos símbolos. Esse jogo que vela e desvela, desmascara o sujeito como criador de si mesmo, o que implica insistir na liberdade da arte. ${ }^{10}$ Não sendo útil, não sendo nem mesmo edificante ou convencional, o esteticismo que baralha arte e vida resiste contra outro artificialismo: o caráter bovarista da literatura do período revestido do valor ideológico necessário para a construção da civilização nos trópicos. O simulacro passa a primeiro plano: ao ser contemplado como tão real quanto sua representação, ele questiona todos os demais simulacros que perfazem a sociedade do fim do século; assim como a trama da arte, as atitudes civilizadas e civilizatórias adotadas pela elite são máscaras que se colam à face. O artista dândi se faz personagem de si mesmo, refugia-se na arte e insurge-se por meio dela.

A reflexão que o culto da subjetividade proporciona confere ao dândi a consciência da miséria da existência humana. Afastada qualquer possibilidade redentora, o dândi permite-se experimentar, o que condiz com sua natureza rebelde. Seu universo é o da imanência e a esfera em que se move é a da matéria. Daí seus objetos serem humanos, mesmo que os tome como coisa, e seu horizonte ser o da morte. O caráter

10 LEVIN. Orna Messer, op. cit., p. 72-3. 
trágico e suicida do dândi reside no seu próprio senso de realidade; irá fatalmente sucumbir ao cotidiano, portanto seria mais digno que colocasse termo a sua existência. A revolta e a tragicidade constituem os elementos de sua modernidade."

O movimento exposto em "Condenado à morte" explicita o caráter fatalista do dandismo; mesmo aferrado à crença na arte, mesmo explorando as qualidades originais de sua sensibilidade, o sujeito contempla sua inevitável condenação

A atmosfera decadista finissecular, acrescida da influência de Baudelaire, também contribui para o dandismo em Cruz e Sousa. Muitos dos heróis simbolistas nutriram o gosto do isolamento como Axël de Villiers de L'Isle Adam e o exótico Des Esseintes de Huysmans. O culto à personalidade participa, no Simbolismo, de uma atitude de recusa frente à realidade circundante.

A inglória majestade do dândi apresenta parentesco com a do anjo caído, Lúcifer. Esse herói, em certo sentido ainda romântico, retrabalha o mito da decadência Seu papel é o de opor-se e nisso aproxima-se de Satã. Ambos inclinam-se contra a maioria, ambos sabem-se fadados à queda e ambos investem suas figuras de martirizadora e bela dignidade. A marginalidade é também a força deste herói; ao concentrar em sua atitude o desamparo e o orgulho do homem revela que "o dandismo é uma forma degradada de ascese"12 Em suas páginas de revolta contra os homens e os ídolos de sua época, o dandismo de Cruz e Sousa investe-se dos anseios satânicos: diferenciar-se do senso comum, fazer valer sua voz de excluído, mostrar um novo rumo para a arte e, evidenciando sua consciência de crise, observar sua trajetória como trabalho de morte.

11 Tomo aqui, como em outros momentos dessa discussão, as reflexōes de Dorf Oehler para quem o dândi de Baudelaire é "uma figura trágico-anacrônica da modernidade". Adiante: "O papel do herói. conferido ao dândi na tragédia moderna, corresponde ao espírito de oposição e revolta, e seu caráter trágico consiste no fato de sucumbir necessariamente na luta contra a trivialidade da existência" In: Quadros parisienses. Trad. Iosé Marcos Macedo e Samuel Titan Jr., São Paulo: Cia. das Letras, 1997. p. 206-7

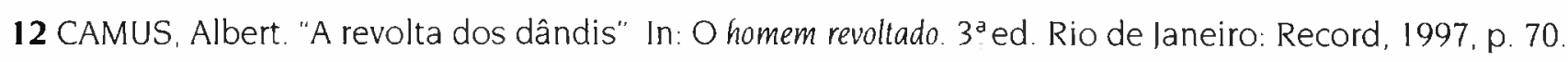




\section{O poeta e os desvalidos: trabalho e marginalidade}

O que norteia o satanismo ligado ao inferno da criação poética e seus impasses é, regra geral também para Cruz e Sousa, o problema do poeta moderno no mercado de trabalho. No Brasil de fins do XIX, a dificuldade de reconhecimento de uma atividade marginal como o trabalho poético, acrescida do preconceito que pairava sobre o homem de letras negro, perfaziam um ambiente hostil ao poeta catarinense que sonhou com o reconhecimento e a glória. O cenário acanhado do Rio de Janeiro da época, os grupos de literatos em torno da Rua do Ouvidor em atitude de arremedo aos hábitos e modo de vida parisienses faziam da capital palco das intrigas, dos sucessos e fracassos da vida cultural. Foi esse meio que o negro loão da Cruz conheceu, local onde aguardou reconhecimento e experimentou frustrações. Os fatos que cercaram sua vida de homem de letras como a empresa arriscada das publicações de Missal e Broquéis, a luta por um emprego digno, o espaço reduzido das publicações em jornais e sobretudo o embate contra o preconceito configuram um quadro de dúvidas, provações e reflexões acerca do papel do artista no mercado das letras. Sobretudo sua obra em prosa da maturidade. Evocações, revela o artista mergulhado em questões sociais de sua época, realidade que a transcriação simbolista refaz por meio de enigmas, impedindo a decifração imediata e exigindo a leitura de seus fragmentos.

A percepção simultânea da história de seu tempo é a de um poeta que visiona antes de ver. Afastada a possibilidade da representação naturalista, os símbolos penetram os pedaços agonizantes da realidade por meio da clarividência do sujeito lírico. Assim como para Baudelaire, o artista deve mergulhar nos abismos obscuros da consciência humana, penetrar na massa de desvalidos que estão, como ele, à margem do processo de modernização. É aí que o poeta encontra a matéria para sua criação poética. Para Baudelaire, a multidão é o lugar onde se enfileira toda a sorte de desvalidos, onde se concentra a matéria-prima da modernidade. Essa multidão não ocorre em Cruz e Sousa, a embriaguez que experimenta não é da mesma ordem: os oprimidos da periferia são os escravos e é essa a peculiaridade do poeta negro. No país de abolição recente, o contingente de escravos libertos engrossava as fileiras da margina- 
lidade. Livres, mas sem condições de trabalho, os negros encarnaram a condição de mercadoria ociosa e desvalorizada. O cenário social que encontra Cruz e Sousa é o de uma marginalidade crescente composta em sua maioria por negros e o do desprezo pelo homem de letras. Das duas situações de exclusão advém a afinidade das dificuldades do poeta com a marginália da cidade pré-moderna.

O trabalho artístico e o trabalho escravo apresentam afinidades que dizem respeito à condição de país periférico. A arte, e sobretudo a poesia, constitui uma atividade marginal no mercado de trabalho moderno: seu reconhecimento é conflituoso, sua utilidade, questionável e sua autonomia, mera ilusão. O parentesco com o escravo funda-se na condição de trabalho periférico. Ambos estão condenados à fatalidade: são anacrônicos e não há lugar digno para eles no mundo que se descortina. Fora da esfera do capital, seja como mercadoria humana desvalorizada (o escravo ou o negro liberto) ou como profissional das letras, a iminência da ruína perscruta-os como tentação suicida

A inebriante multidāo onde Baudelaire pretende perder-se a fim de tomar parte desse contingente de miseráveis, esse espaço de travejamento da alteridade é substituído em Cruz e Sousa pela afinidade que vem do sofrimento e da dor negra; através de seu grito, ele concentra o dos outros e mostra-se sensível à massa de desvalidos. Num movimento do eu reduplicado, o eu entrevê outros do mundo dos vencidos. Em dois momentos de sua prosa, pode-se observar o entrelaçamento entre os representantes dessa massa:

(Ó Noite)... que fazes caminhar todos os espectros, ressuscitar todos os mortos, máscara irônica de todas as chagas; confessionário de todos os pecados; liberdade de todos os cativos: como eu recordo a galeria subterrânea dos teus mórbidos bêbados, dos teus ladrões cavilosos, das tuas lassas meretrizes, dos teus cegos sublimes e formidáveis, dos teus morféticos obumbrados e monstruosos, dos teus mendigos teratológicos, de aspecto feroz e perigoso de tigres enjaulados, acorrentados na sua miséria, dos teus errantes e desconsolados Cains sem esperança e sem perdão, toda a negra boêmia cruel e tormentosa, ultra-romântica e ultratrágica, dos vadios, dos doentes, dos degenerados, dos viciosos e dos vencidos!13

13 SOUSA, loão da Cruz e, op. cit., "A noite". p. 571 
Ele viu atirarem-se convulsamente os leprosos, os aleijados, os epilépticos, os morféticos, os tísicos, os cegos, enroscados todos na sua negra mortalha de suicidas, cambaleantes, ébrios de dor, de desespero, na agonia da carne que se dilacera, que se rasga, que se despedaça - enquanto o soberbo sol, dos Altos, como um pagão bizarro, cantava sobre todas essas chagas abertas, sarcasticamente, diabolicamente, indiferentemente, a música offenbachiana, do seu clarão comunicativo e cortante...14

No primeiro trecho, sob a máscara da noite, símile e confidente do poeta, encontram-se aqueles marcados pelo supremo sofrimento que os dignifica e ensandece. A noite permite a tais seres a liberdade, ela surge simbolicamente como o espaço dessa sinistra procissão de vencidos aos quais o poeta se assemelha. O segundo trecho evidencia um poeta vidente que observa, afastado, a vertigem suicida dos homens. A contemplação da indiferença da natureza ("o sol... cantava sobre todas essas chagas abertas, sarcasticamente") dá a medida da descrença em qualquer possibilidade de salvação. O sol surge como portador de um canto infernal, revelador de uma realidade fora dos eixos. Esta espécie de riso frente à miséria humana partilha de uma natureza satânica: faz desmoronar a idéia de totalidade, aniquila a falsa compaixão e oferece, pelo caminho inverso da crueldade, outra possibilidade de redenção.

A afinidade com a massa de excluídos se dá através do recorrente deslocamento de narradores que erram pelos seus poemas em prosa representados pela figura do bêbado, do louco, do velho, do idiota. Talvez como influência de Baudelaire, a matéria poética do negro encontra respaldo e prosseguimento nessa humanidade de desvalidos quase ensandecida pelo sofrimento e miséria. A dor desses indivíduos os aproxima de uma quase vidência, como se a obnubilação da razão, significasse o caminho para uma outra forma de conhecimento. Essa nova possibilidade de travejamento da realidade é composta por enigmas que os símbolos dos poemas engendram no espaço do sonho e do inconsciente. É assim que muitas vezes a percepção da desfiguração dos seres e imagens, numa espécie de êxtase agônico que beira o inorgânico e a aniquilação da matéria, é realizada por um personagem retirado da escória da humanidade. Aos personagens eventualmente mais distantes da civilização ou da ra-

14 Idem, "Condenado à morte" p. 542-3. 
zão é dada voz poética clarividente, cuja iluminação dá conta do crescente e impiedoso processo de reificação.

O resgate das vozes se dá através de um processo dilacerante. É dialeticamente do culto à dor do poeta negro que advém a valorização do outro marginalizado e de si mesmo. Assim o princípio de valorização do eu às avessas: através da dor do artista negro, o poeta assume o lugar de fala e discursa em seu nome que, no sentido do narrador duplicado que fala por si e pelo outro, aponta para o vislumbre de vozes emudecidas, do anseio de uma coletividade. O outro é travejado pelo narcisismo ora melancólico, ora sádico desse eu que encarna o enigma constante da multiplicidade de matizes da questão do satanismo. O movimento do eu reduplicado desvela vozes soterradas que escavam nas variantes do mal o seu eco.

O poeta cercado pelo seu meio, pela sua raça, pela natureza de sua atividade e identificação com a massa de excluídos constitui as faces do drama do artista moderno em Cruz e Sousa. Esse doloroso lamento dirige-se a Satã, o "branco Lusbel das cruéis clarividências... patrono dos miseráveis e daqueles que se aventuram rumo ao desconhecido.

\section{3. "O sonho do idiota": clarividência e sacrilégio}

O poema em prosa "O sonho do idiota" promove a transformação do espaço sagrado em inferno entrevista por um narrador marginal. O poeta empresta sua voz a um representante desta escória da humanidade e lhe dá o poder de divisar, através de símbolos, a decadência de um conjunto de ideais - a razão, o progresso, a crença na salvação. Ao idiota é possibilitada a percepção reveladora e inquietante. Afastado da razão, a doença lhe dá uma outra possibilidade de visão, onde as imagens inconscientes traduzem estados de alma e proporcionam a observação de um espaço alterado. Esse "ser hediondo" belo e triste, possui talvez a intuição de um "emissário celeste" no sentido daquele que vê o que não está dado, e, transcendendo a realidade. aponta para outro princípio de vida. 15

15 Em Missal, o poema em prosa "Sob as naves" prenuncia "O sonho do idiota" No primeiro há tam- 
Sonhador em vigília, esse idiota penetra o templo sagrado escondendo-se das admoestações da multidão. Embriagado pela liturgia e eclipsado pela turba, o homem deixa-se trancar na igreja sozinho, sem que sua falta seja notada. Abala-se pela espiritualidade que sente emanar de uma imagem da madona e encontra-se transfigurado pela graça benevolente que vê efluir do ícone. Em meio a tal estado de embriaguez e tomado de repentina iluminação, o homem questiona a força que mostrou tamanha consolação, prevendo que tal estado seria efêmero. E, confundindo o gozo místico com a atração carnal da mulher sob o manto da madona, vê-se invadir de tortuosa inveja pela graça entrevista de um mundo que não é e não será o seu. Tal sentimento corporifica-se em vermes, répteis e substâncias verdes que saem de seu corpo, enroscam-se nas imagens e selam a condenação do mundo celeste anteriormente entrevisto. Arrastando-se alcança a porta da igreja, espécie de saída desse inferno, e percebe que esteve sonhando. Mas, num momento de vidência sobre seu estado, reconhece que seu sonho continuará, que a realidade é seu pesadelo.

Neste poema, o satanismo surge da entrevisão do narrador-idiota. Trata-se do satanismo vidente, o do iluminado Lusbel que permite divisar mundos desconhecidos. A descrição do espaço e suas implicações permitem observar até que ponto o estado do sujeito é projetado sobre o mundo exterior. A igreja, "templo iluminado" apresenta-se inicialmente, seguindo os passos da tradição clássica, com conotação de locus amoenus, refúgio buscado pelo idiota, recinto de pureza e espiritualidade. A descrição salienta o caráter do lugar sagrado como refúgio aprazível:

Uma vez ermo e hirsuto como um dromedário sonolento errava pelas ruas escuras de certa cidade sombria, o pobre idiota foi corrido por apupos, pela chacota irreverente e

bém a temática da profanação do espaço sagrado e da imagem da madona, no entanto, não há presença do elemento grotesco: "Eu sentia, sob aquelas rígidas carnes mortificadas, frêmitos vivos do sangue envenenado e demoníaco do pecado.

E. de repente, não sei porque profana, tentadora sugestão, vi nitidamente Nossa Senhora descer aos poucos do altar, branca e muda, arrastando um manto estrelado, e, vindo anelante para mim, de braços abertos, dar-me, com os olhos claros de azul, profundos e celtas, infinitas, inefáveis promessas... In: SOUSA, João da Cruz e, op. cit., p. 462. 
apedrejado e penetrou, acolhendo-se, - massa mórbida, riso amolentado, aparência monstruosa de hidrocéfalo - a larga porta aberta de um templo iluminado. 16

e segue contemplando outros sentidos igualmente agradáveis: olfato, audição, tato: "um perfume celeste errava, vivo e intenso, no ar, evaporava-se lânguido das névoas brancas dos incensos" "O orgão nebuloso e sensibilizante (...) expirava com eternecimentos melódicos, com taciturnas almas sonâmbulas, deixando no ar a pungente melancolia fugitiva de um esquecimento amargo... "No recinto agora bizarros alvoroços passavam... Um zunzunear de turba que ondeia e que murmura (...) aquela ondulação de corpos ia e vinha, circulava para a direita, para a esquerda, subia e descia, para baixo, para cima, estuando, com a respiração de desabafo de um grande monstro saciado. O sujeito sente-se dominado por uma atmosfera quase mística cujos sons, odores e demais sensações parecem ecoar o estado de êxtase em que se encontra. As sensações entrelaçam-se e ressoam umas nas outras cujo desenrolar sinestésico lembra os pressupostos da teoria das correspondências de Baudelaire

A suposta pureza litúrgica marca a caracterização do espaço e o transforma: “(...) transfigurado por um sentimento de infinita doçura, que o tornava quase belo' 0 idiota sente-se penetrado por algum mistério e associa tal sensação à visão da madona

No entanto, o espaço transforma-se. Antecipando a metamorfose, o narrador encarna a aflição do idiota na pergunta: "que inferno nunca sonhado tinha posto ante os seus olhos inúteis e desprezados essa luz consoladora, essa luz que ele jamais sentira, tão bela e tão funesta, aparecendo na serenidade dessa manhã dentro do templo iluminado?" Reconhecendo sua condição inevitável de excluído, o cenário dá lugar ao locus horrendus. Sob o imperativo da cor verde, índice de putrefação, répteis invadem o espaço invertendo o refúgio em refugo e promovendo a metamorfose do espaço sagrado em inferno. O instrumento que permite a transformaçāo é o próprio corpo do idiota, dele procedem os vermes, seu corpo é meio transmissor da morte

(...) o idiota como um monstruoso reptil verde, sentiu-se subdividido, multiplicado infinitamente em milhões de bilhões de reptis verdes de todos os aspectos e formas, lon-

16 Idem, "O sonho do idiota" p. 633 
gos, lentos, elásticos, subindo pelos altares, descendo pelos paramentos, viscando as vestes dos Santos, se arrastando pelas asas, pelos frisos das colunatas, pelo arco cruzeiro, tatuando de verde a prata das lâmpadas e subindo, sempre triunfais, avassaladoras, sufocantes, numa peste verde, numa alucinação verde, até o altar-mor, sobre o cibório de ouro, sobre o cálix de ouro, sobre a Cruz do Cristo de ouro, esmerdeando maravilhosamente com bizarrismos bizantinos de formas as requintadas cinzeluras refulgentes, de níveas claridades puras e brumosas de Via-Láctea, da velada e suntuosa capela de reverências, tabernaculal, do Santíssimo Sacramento. 17

O recinto apodrecido desperta terror no homem que procura fugir. O seu drama torna-se tanto maior quanto percebe que a libertação é impossível: os vermes nascem de sua terrível condição e impõem-se talvez como castigo à profanação do templo que sua presença acarretou. Ao transformar-se em parte do inferno, corpo de onde emana as marcas do apodrecimento, o homem reconhece o mal em si: ele é seu próprio pesadelo.

O que promove a mudança, o estopim da alteração responsável pela figuração do inferno no recinto sagrado, é a relação do idiota com a mulher. Desde o início da descrição da imagem, ainda tomado da espiritualidade proporcionada pelo locus amoenus, ele vê a madona como mulher: "(...) a boca deliciosa e doce, na expressão cândida, infinitamente delicada, da carícia sutil de beijos alados" A beleza pagã da imagem confunde-se com a graça celestial que transmite. Observa-a como objeto e ser superior que, dada sua benevolência e poder, o absolve de sua culpa. Desejo e transcendência estão na base do sentimento que lhe dá vidência:

E esse sentimento que o transformava e que ele próprio desconhecia assim tão intenso e curioso na sua alma, transcendentalizava-o e dava-Ihe ao obtuso idiotismo uma como que supervisão, certa regularização lúcida e nobre, fazia-o por instantes viver, reflexamente, na origem ignota de uma especial percepção mental e de uma extravagante emoção. ${ }^{18}$

17 Idem, op. cit., p. 639

18 Idem, op. cit., p. 635 
A imagem "ao mesmo tempo carnal e mística" cumula-o de bênçãos e sortilégios e parece mesmo absolvê-lo de sua culposa miséria. A paixão que vive tem um fundo que entrelaça misticismo e sensualidade, deseja a comunhão místico-carnal com a imagem da madona, mas teme violar sua pureza no contato com sua terrível dor de idiota:

Podiam ligar-se, pois, ele e ela, no mesmo fundo de abstratas purezas, prender-se pelas mesmas espirituais correntes, fundir-se nos mesmos emotivos espasmos... Não! ele não violaria os melindres, os escrúpulos arcangélicos daquela natureza delicada, não iria empanar os cristais impolutos das esferas azuis onde ela triunfava. Podia, pois, reentrar, pura, inviolada, nos seus sacrários de ouro, nas suas preciosas redomas, nos seus majestosos domínios e reinados de formosura, incensar-se com o seu perfume de sempre, porque nada inteiramente nela nem de leve experimentara o contato sutil das secretas e tortuantes emoções dele. ${ }^{19}$

A percepção de si como ser oposto ao objeto desejado - a imagem - é prenúncio de constatação de si como inferno. Tal momento clarividente significaria o adeus as suas ilusões, o que implica a constatação do prosseguimento de sua dor e da petrificação de sua condição de excluído. "Sim! não era ela nada mais do que a encarnação palpitante de sua visão, a cristalização de suas fugitivas saudades e ilusões, que por aquela embaladora e fugitiva forma vinha dizer-lhe o melancólico, o aflitivo, o desesperado adeus para sempre.

Muitos são os índices da transformação do espaço que culmina numa espécie de êxtase do texto, no sentido do coroamento da figuração do inferno como espaço de liberdade e morte. Mas o momento da alteração central do poema é percepção da mulher identificada ao mundo do qual o idiota foi afastado e para o qual olha com "a baba verde da inveja" Essa inveja expõe dois mundos e escancara a condição do idiota. Encarnado na mulher está um mundo inacessível: "Sim! Ciúme desesperado por vê-la de outro, por senti-la nos braços de outro (...) Sim! Ciúme feroz e inveja ainda mais feroz por ver-se idiota, inerme e inútil para florescer, para brilhar ao lado de outro homem são e forte que a desejasse, que a possuísse!"

19 Idem. 
Do contato com a madona profana irrompe o grotesco. Como se a relação com a realidade desencadeasse o estranhamento, o espaço se altera a partir da visão da imagem e as ordens do mundo confundem-se. Na confusão de domínios, o animal funde-se ao humano e, desta inversão, advém um estado em que o estranhamento e a angústia substituem o chão firme da realidade. Surgido da voragem visionária do demente, os vermes apontam para um mundo demoníaco cuja anulação das ordens enceta o sinistro numa situação onde desponta o absurdo. O império do absurdo revela um mundo conduzido por uma vontade irracional que move os homens e as coisas, correlato da idéia de que o mundo é representação 20 . O homem não passa de um boneco manipulado por uma vontade soberana, de cujos mecanismos o sujeito encontra-se alheado.

O templo transformado em inferno dá conta da representação de um mundo alheado. O grotesco é o absurdo que irrompe do espaço reconhecível da igreja, firmando uma nova ordem desconcertante que abre uma fenda abismal na forma e no sentido encarnados pelo espaço sagrado. O lugar das quimeras e da redenção possível traveste-se de índices demoníacos, investindo o espaço familiar com os signos do sinistro.

Da perspectiva do grotesco, a realidade e o homem participam da mesma cisão, o estranhamento daí decorrente verte em horror a perspectiva de um horizonte redentor. Nesse mundo povoado de demônios, uma espécie de libertação às avessas é insinuada: por meio da arte, do sublime tornado grotesco, a realidade é horrorizada e o homem pode enfrentá-la.

O espaço sagrado vertido em matéria putrefata assinala o impasse da constituição da alteridade desse narrador que é um duplo. Prazeres místicos ou materiais não são destinados a um idiota. Longe do mundo das mercadorias, dos prazeres e da

20 Influência constante no período simbolista, Schopenhauer e sua doutrina da vontade enquanto representacão, contamina, neste caso, a noção de representação artística. Comenta Anatol Rosenfeld sobre Schopenhauer e sua influência na arte moderna em "A visão grotesca" In: Texto e contexto. São Paulo: Perspectiva: Brasília: INL, 1973, p. 66. "Na sua essência a vontade irracional o homem já não difere dos animais, nem das plantas (...) A ordem é apenas aparente, no fundo reina o caos. (...) Agitamo-nos num mundo de aparências, de máscaras, num mundo que é 'representação"." 
razão, seus desejos transfiguram-se em vermes. O mundo exterior contemplado pelo idiota apresenta-se como reflexo de uma subjetividade em convulsão. A deformação do espaço é decorrente da força de uma realidade interior que, longe dos pilares da razão, adquire certa vidência. Nesse sentido, a desconstrução operada destaca-se como procedimento de fundo expressionista. Deformação desencadeada pela força de uma realidade interior atordoante. A realidade que se deteriora, que se desrealiza rumo ao absoluto informe, conduz a um sujeito sem representação. O escorrer de vermes e matéria putrefata conduzem a alteridade do demente à mera aparição fantasmática. Sob o signo do grotesco, delineia-se o espectro da alienação. A interioridade que desencadeia a transformação grotesca do espaço instaura o efeito de estranhamento. Tal sujeito que se desconhece parece afirmar que por meio do mal - e sob a égide da morte - a arte inscreve uma possível libertação.

Aqui o mal, no sentido das formas hediondas que desvelam um mundo desprovido de sentido, adquire "a pretensão de assimilar a matéria na forma de seu desejo"2l O idiota, travestido do olhar vidente, abraça o mal como meio de afirmar alguma forma de poder. Poder cuja filiação satânica retira de um estado de impotência; força do excluído que se sabe condenado à morte. Os objetos de seu desejo metamorfoseiam-se e contaminam o espaço e a bem aventurança prometida pelos céus. Sua demência chega a afastar a dualidade bem/mal e ostenta o triunfo do informe, arte do feio e do grotesco. ${ }^{22} \mathrm{O}$ verde que escorre do recinto sagrado marca o fracasso do reconhecimento de si como alteridade possível, perfazendo seus anseios e desejos soterrados em matéria podre. Como um corpo, a consolação celeste se putrefaz, escancara sua temporalidade signo de morte.

A "esmola santa da morte" escorre pelos santos do altar e imprime a fatalidade do apodrecimento terrestre no templo enquanto simulacro da vida eterna. As lamas verdes dão imanência ao mundo dominado pelo ideal, trazem a morte e o impé-

21 VIGNOLES, Patrick. "Qual é o mal senão o fato de pretender assimilar a matéria na forma de seu próprio desejo?" In: A Perversidade. Campinas: Papirus, 1991, p. 137

22 O paroxismo do mal implica a abolição do bem e do mal promove o informe, no sentido da destruição das belas formas da civilização e da arte. Ver VIGNOLES, Patrick, op. cit., p. 60 e 91 
rio da matéria. A cor do apodrecimento contrasta, ainda, com as cores litúrgicas: com o branco emissário da pureza ou o vermelho das vestes sagradas, tonalidade que denota poder e apreende o sangue do sofrimento redentor do Cristo. A igreja como palco da transformação satânica expõe a falência das instituições cristãs e das promessas de revelação. A decomposição esverdeada corrompe a nitidez ofuscante da salvação e o corpo da morte se faz estrutura

A demência insinua-se como duplo do poeta no sentido do parentesco entre as condições marginais, mas é também aspecto que se comunica com a problemática da criação, remetendo ao mito do poeta louco. O louco como aquele cuja intensidade da vida interior contrasta com a frouxidão dos laços com a realidade. Assim como o poeta, um desadaptado cuja distância da vida mundana permite que de seu merguIho nas profundezas do eu emerja a face opaca do real. Se "a loucura constitui a última gradação do alheamento do mundo"23, o poeta na figura do demente, revela-se uma espécie controversa de vidente alheado. É do fundo de sua condição de alheado que sobrevém a vidência do absurdo no que este possui de reflexo invertido da caducidade do mundo24, como uma espécie de "revelação profana"25 O mundo estranhado entrevisto pelo idiota materializa-se enquanto realidade, uma das representações possíveis do mundo com vontade própria

Sob a égide do registro grotesco, as ordens do mundo apresentam-se ani-

23 KAYSER, W. O Grotesco. São Paulo: Perspectiva, 1986, p.71

24 Idem, p. 159: "Na demência, o elemento humano aparece transformado em algo sinistro; mais uma vez é como se um id, um espírito estranho, inumano, se houvesse introduzido na alma. O encontro com a loucura é como uma das percepções primogênitas do grotesco que a vida nos impinge. Nas suas representações do grotesco, o Romantismo e a arte moderna serviram-se desse motivo com notável freqüência. Mas, ao mesmo tempo, tal fenômeno nos transporta para a 'poética da criação' Desde cedo, surgiu a determinação de que, ao lado do sonho, a loucura ou quase-loucura eram a atitude correspondente ao artista

25 O termo é de Walter Benjamin em "O Surrealismo - o mais recente instantâneo da inteligência européia' In: BENIAMIN, Walter e alii. Textos escolhidos. $2^{\text {a }}$ ed. São Paulo: Abril, 1983, p. 85 (Os pensadores). Tal expressão é utilizada para destacar certa irradiação presente nas imagens surrealistas cuia "revelação" não é da ordem do divino, mas do terreno. 
quiladas conduzindo a personalidade e a história ao mesmo torvelinho destruidor. No entanto, é o império deste verde putrefato que promove uma construção por sobre os estilhaços de um mundo esfacelado: o grotesco estetiza e revela uma visão da história. No confronto do mundo desordenado, do narrador-poeta na pele do idiota, as tensões conduzem a um discurso ruinoso: o grotesco organiza a destruição.

A vidência do idiota permite o vislumbre de sua condição social. Às promessas de alteridade e redenção, destinadas a outra classe, a supervisão do poeta sob a máscara do demente oferece o apodrecimento da matéria ${ }^{26}$ A imagem de um templo que se deteriora e se tinge de verde, vem na contramão das imagens positivas fornecidas pela sociedade da época em seu anseio civilizatório. Evidenciando o duplo do poeta, a madona é redentora e mulher do mundo dos brancos, os objetos e o espaço sagrados também destinam-se a poucos e não trazem o perdão para aqueles que foram excluídos da civilização. Daí o espaço transfigurar-se em inferno, correlato cifrado da história enquanto ruína.

O inferno em "O sonho do idiota" é marcado pelo domínio da categoria do insólito, reflexão do sujeito sobre a morte que promove a alucinação. A forte presença da morte dá vida ao inanimado, adentrando a fronteira do que está além.

O narrador empresta sua voz e olhar a um personagem idiota. Àqueles eventualmente mais distantes da civilização ou da razão é dado o poder clarividente. O verde da matéria podre corroída por vermes é fantasmagoria que revela sondagem profunda de aspectos da sociedade que traça o lugar fixo dos homens. Na contramão das imagens civilizatórias, os símbolos verdes cunhados pelo poeta constatam a fatalidade da morte inglória e a impropriedade do otimismo no progresso dos homens. Sobretudo oferecem à possibilidade de redenção prometida pelos céus, a vertigem da matéria perecível e soberana. E insistem na "estética do feio" como instância capaz de vislumbrar o processo de alienação

26 Tal estado de vidência do idiota como duplo do poeta remete à "lettre du voyant" de Rimbaud. O poeta deve fazer-se vidente por meio de um "desregramento de todos os sentidos"; o idiota-poeta adentra os limites do desconhecido pela construção de um mundo às avessas. In: RIMBAUD, Arthur. Poèsies. Paris: Booking Internacional, 1995, p. 190. 


\section{O "Emparedado": o fazer poético e o impasse da Constituição da Alteridade}

A voz que foi dada a um representante da marginália em "O sonho do idiota" agora é encarnada pelo sujeito lírico que se confunde com o poeta. Evocações é livro que se desdobra em vozes remetendo à voz que grita o sofrimento do artista negro. A percepção da ruína dos ideais da arte e das promessas da civilização conduz o sujeito lírico a buscar, nas realidades eventualmente distantes dos pilares da razão e no crivo do poeta visionário, o olhar iluminado, disposto a oferecer, trevas clarividentes cunhadas pela linguagem poética, os tormentos recalcados do sonho e do inconsciente. Desdobramentos da idéia de que o mal é legião, esses seres escavam a dor e evidenciam um mundo desprovido de sentido.

O "Emparedado" talvez seja o poema em prosa mais famoso de Cruz e Sousa. Testemunho de sua condição de poeta negro num país escravista, o poema foi muitas vezes tomado como exemplo para leituras puramente biográficas. O drama do artista negro estaria explícito e provaria, entre outras coisas, como ele ansiava por livrar-se das amarras que impediam sua ascensão social. Por outro lado, o texto serviu também como prova de que o poeta reconhecia a si mesmo como negro e estava, portanto, ao lado dos abolicionistas. No entanto, as posições acima mencionadas não levaram em conta a tensão interna do texto que o faz oscilar entre duas percepções de si que, presentes na forma, dotam o texto de agudas dilacerações. ${ }^{27}$

27 volume da coleçāo Fortuna crítica de Cruz e Sousa, organizada por Afrânio Coutinho, contém exemplos das apreensões críticas em relação a "Emparedado" Nestor Vítor refere-se ao poeta negro que lutava contra o preconceito: "o Emparedado (...) não é apenas um soluço de revolta pessoal, mas da de toda uma raça proscrita pela Civilização inteira, que desdenha quanto pretenda em tais homens ser manifestação de vida superior"(p. 133), Carlos Dante de Moraes enfatiza o protesto do negro contra o cientificismo: "Aí é urdida uma dialética dramática, absolutamente inédita em nossa literatura, por meio de protestos, gritos, gemidos, invectivas, desafios, uma cólera de profeta bíblico e um amorpróprio que sangra e arremete com o furor da onda empolada (...). O protesto mais grave, porém, é contra a 'ditadora ciência das hipóteses' que divide as raças em superiores e inferiores, negando a estas a capacidade e os dons mais altos do espírito." (p.271). Eduardo Portella aponta o caráter social 
O poema que versa o tema do poeta soterrado reveza duas percepções da mesma dor cujo movimento dialético nega constantemente uma postura hegemônica. A tradicional leitura de seus recortes presta-se a interpretações que impedem a percepção da negação e denegação constantes de seus conteúdos. Não permite observar o deslocamento da constatação da identidade no desdobramento do eu e do outro. Movimento que mostra reconhecer as marcas da ideologia e procura delinear um discurso contra-ideológico.

O texto narra a via-crucis profana do poeta empreendida pelos caminhos tortuosos da arte e dos dilaceramentos resultantes da impossibilidade científica e social da inserção do poeta negro na República das letras. Relato quase autobiográfico, afasta-se da pura confissão pela alternância de vozes e pela torrente de símbolos que divisam obra, vida e história. A simultaneidade de aspectos que correm as páginas de Evocações: o tom blasfematório, a fatalidade melancólica do sujeito que reflete o absurdo da existência, o negro como símbolo multifacetado concorrem para que o "Emparedado" figure como uma espécie de texto-síntese da obra em prosa de Cruz e Sousa. Referencia os ideais malogrados de Missal, dialetiza a dor como meio de purgação e redenção do sofrimento e mostra o poeta simbolista preso aos encantos fatais da arte. $O$ "Emparedado" fecha, evidenciando a idéia da arquitetura do livro, o ciclo que começa por "Iniciado" primeiro poema em prosa de Evocações. 28 De iniciado a emparedado, as

do texto: "No tema do 'emparedado nele está o condicionamento social da sua poética" (p. 305), Fernando Góes destaca o aspecto confessional de "Emparedado" cujas páginas dão conta da revolta contra o meio: "Mas o capítulo mais significativo, aquele em que Cruz e Sousa mais se confessa, aquele em que fotografa sua angústia e sua revolta, é o do 'Emparedado' Páginas quase que de ódio, onde não ataca ninguém, mas acusa e responsabiliza o meio, o ambiente preconceituoso e maldoso que o desamparou" (p. 344). Em nenhum dos casos citados acima há a observação do caráter duplo do texto, o que implica uma apreensão unilateral. Entretanto, estudos mais recentes apontam a percepção do eu como tu: é o caso de Alfredo Bosi que refere o caráter contra-ideológico do texto "Sob o signo de Cam" In: Dialética da Colonização. São Paulo: Cia. das Letras, 1992, p. 266-72 e de Ivone Daré Rabello: "Numa lucidez extraordinária, faz ouvir (o poeta) a voz da ideologia que, sinistramente, nasce de dentro da própria subjetividade" Um canto à margem. São Paulo, 1997, 150 p. Tese (Doutorado em Teoria Literária e Literatura Comparada) - FFLCH. Universidade de São Paulo.

28 Note-se que o poema em prosa "A lanela" de Missal prenuncia o tema de "Emparedado" De forma 
etapas de Evocações traçam um sujeito que marca o passo com a derrocada das ilusões atrelada ao sentimento de iminência da morte.

"Emparedado" começa com uma invocação à noite. Símbolo que evidencia sua dupla face, a entidade aponta para as trevas e a morte, mas também para a fecundidade do sonho e do esquecimento. A presença da noite remete a outro poema em prosa também de Evocações, intitulado justamente "A noite" Trata-se de texto de louvor à noite, espaço fecundo e acolhedor, revelador de dores e instigador de sonhos. Diversa da noite luminosa e hospitaleira de Missal, ela apresenta-se como o espaço de travejamento do outro, além de evocar sua força liberticida. Espécie de máscara mortuária que adentra camadas profundas do pensamento e da experiência, é musa inspiradora, espaço de evasão e momento que permite divagações. Tomada enquanto objeto, espaço e tempo, a noite encarna o desejo de inserção do poeta no mundo e seu oposto; a possibilidade de se evadir desse mundo que o excluiu.

Lê-se em "A noite" a expressão: "Hóstia negra dos sonhos brancos que eu eternamente comungo" O enigma desta frase repõe as múltiplas significações do símbolo noite: o corpo negro eleito - talvez como Cristo - pelo e para o martírio e sonhando com mundos mais próximos da idéia de humanidade ou o corpo negro sofrendo pelo sonho branco (seja o trabalho ou o sofrimento recompensado pelo paraíso cristão) ou ainda, como quer o símbolo mais latente no texto, a hóstia negra como a noite que oferece sonhos somente para os brancos.

O movimento de opostos prossegue: a noite permite o sonho e o entorpecimento, irradia quimeras e oferece a desolação, possibilita a ascensão a mundos desconhecidos e desnuda os subterrâneos onde se encontram os miseráveis e os vencidos... Esperança e morte são, pois, as duas faces da evocada noite, cuja atração pelo aniquilamento, ao final do texto, reveste-se de melancólica volúpia. Os chamados à morte têm o correlato de uma imagem luminosa: "irradiação" "cristalização":

ainda incipiente, o tema do sujeito encarcerado, oprimido já está posto neste poema em prosa. A mesma metáfora do muro como obstáculo ao sonho e ao auto-conhecimento é utilizada. O processo de exclusão social e alienação já havia sido, pois, vislumbrado. 
Ó bendita noite! dá-me a morte na irradiação dos teus raios, para que eu rompa o selo cabalístico dos teus segredos; dá-me a morte na cristalização dos teus astros, nas auréolas das tuas nuvens, no pesado luxo das tuas constelações, no vaporoso das tuas visões de lagos, na solenidade bíblica das tuas montanhas enevoadas, nas cerradas cegueiras apocalípticas das tuas maravilhosas florestas virgens, quando lentas luas langues florescem nos céus como grandes beijos congelados de brancas noivas gigantes encantadas e mortas... ${ }^{29}$

A reflexão promovida em "Emparedado" tem como palco a noite, "hora infinita da Esperança" é ela quem desperta o desfile dos sonhos, das angústias, das desilusões e da dor do sujeito lírico. Como uma parábola, o sujeito narra seu caminho, suas provações até o momento em que chega à beira de "caóticos, sinistros despenhadeiros" e, como Lúcifer, conhece a queda: "como outrora o doce e arcangélico Deus Negro, o trimegisto, de cornos agrogalhados, de fagulhantes, estriadas asas enigmáticas, idealmente meditando a Culpa imeditável... A culpa do sujeito, "nefando Crime" é a de ser um artista que pertence a uma raça considerada bárbara. O parentesco com Satã conduz ao pecado primordial: haver afrontado o poder, acreditando na força do sujeito e saber-se fadado ao fracasso. A culpa imeditável aponta para o paroxismo que advém do mito bíblico dos filhos de Cam e a culpa resultante do conhecimento do mal. A consciência de cumplicidade em relação às dores do mundo implica paradoxalmente o remorso e a pulsão de morte que, aliados à culpa, são índices de que o sujeito lírico pensou o mal como realidade.

O tom blasfematório, de profunda heresia e revolta, caracteriza um sujeito lírico que escancara seu ódio. Esse sentimento refere-se à consciência da condição humana, à sua própria condição de excluído e à proclamação de um mundo sem deuses. A revolta insere-se no seio desse grito, fazendo com que o eu reflita sobre o mal físico, corporificado na escravidão, e moral, daquele que traz a culpa da cor

Apesar do tom confessional, o texto afasta-se do puro relato autobiográfico devido ao diálogo que se estabelece entre o eu e o outro. O movimento que alterna a voz na primeira e na segunda pessoa desvela um percurso reflexivo que permite reco-

29 SOUSA, João da Cruz e, op. cit., "A Noite" p. 540. 
nhecer em si os traços da ideologia que o excluiu. O sujeito lírico revela-se um duplo: ele é o poeta que padeceu os tormentos de sua cor e ele é aquele que observou o percurso do poeta. O movimento de duplicação permite que se observe o outro em si; reconhece em si as marcas da ideologia oficial e a partir daí cunha sua resposta contraideológica. E a resposta do eu dá-se por meio da introjeção dilacerante dos valores de uma sociedade que o excluiu. O poeta encarna satanicamente o discurso cientificista da época, que considerava o negro um ser inferior, fadado a permanecer na barbárie. O discurso cientificista é encarnado e dialetizado em seguida:

O temperamento entortava muito para o lado da África: - era necessário fazê-lo endireitar inteiramente para o lado Regra, até que o temperamento regulasse certo como um termômetro!

Ah! incomparável espírito das estreitezas humanas, como és secularmente divino!30

Aparentemente, o primeiro enunciado cola-se à ideologia, encarnando o discurso científico acerca do negro. Mas a frase seguinte atua como proposição irônica frente ao conteúdo anteriormente exposto, instaurando um núcleo de dúvida em relação às primeiras afirmações. O narrador da segunda frase identifica o emissário da primeira, o "incomparável espírito das estreitezas humanas" e introduz a ironia: "como és secularmente divino!" Aquilo que é estreito torna-se divino, a ironia atua como correlato recorrente das inquestionadas verdades oficiais. A forma, no desdobramento constante do duplo, assume a disposição de negar e denegar conteúdos que se referem ora às marcas da ideologia oficial, ora às regras do decoro estético.

A estrutura dialógica revitaliza os discursos cientificistas por meio da lógica satânica da traição: em terceira pessoa, o sujeito, cujo desenrolar do texto expõe como duplo, encarna os preceitos que procura atacar. O próprio movimento do eu que se desdobra implica negação da voz persecutória em terceira pessoa, desvendando um sujeito que identifica ideologia e história por meio dos antagonismos vividos por um artista negro num país escravista. O movimento de vaivém permite a percepção da fi-

30 Idem, "Emparedado" p. 662. 
siognomonia dos impasses do Brasil do período na figura do homem negro de letras: processo civilizatório e escravidão na voz negra que desvela, nega e denega os liames do cientificismo e dos não-ditos da ideologia oficial.

O eu que fala a um tu transforma o sujeito em objeto como faz a morte. Assim, o enunciador em primeira pessoa explicita um ódio que "contesta ao ser odiado seu direito à existência"31 Isto é, o eu contesta o direito ao tu de viver, o que significa questionar a si mesmo o direito à vida. O "Emparedado" experimenta-se como signo profético da morte: é realidade e símbolo, em sua dor e em sua carne sofre e promove o mal.

O tema do "emparedamento" evoca E. Allan Poe. As paredes que se fecham encarcerando o sujeito, suas aspirações e iłusões como metáfora da subjetividade inseparável da opressão do mundo exterior. No caso de Cruz e Sousa, a metáfora remete ao processo de exclusão social do qual foi vítima. Imagem do soterramento dos ideais e da difícil construção da alteridade.

O lugar de fala do sujeito é o daquele que se reconhece desconhecendo-se. Reconhece os estatutos de uma sociedade de base escravista e cientificista e desconhece sua suposta natureza de bárbaro. Desconhece os caminhos contraditórios de seu desejo de inserção no mundo dos brancos, reconhecendo sua situação de homem e artista negro, exilado e condenado à morte. O papel do duplo é também o do estranhamento: o sujeito é e não é ele mesmo, o desdobramento do eu permite a observação do impasse da constituição da alteridade. A voz do excluído, ao desdobrar-se, e atingir o paroxismo, expõe a dificuldade de representação da alteridade do negro. O irrepresentável des-

31 BORNE. Etienne Le problème du mal. 4a ed. Paris: Presses Universitaires de France, 1967, p. 33: "La haine nie d'abord la liberté de l'être abhorré, la change en destin, transformant le sujet en objet, comme fait la mort. Ensuite d'une façon moins symbollique et plus réaliste, la haine conteste à l'être son droit à l'existence. Mais en même temps la haine approuve le monde être ce champs clos, cette nature athée où triomphe la mort. Toute haine est, à la limite haine de Dieu, poursuit la mort de Dieu. Le nihilisme est la métaphysique de la haine." Em tradução literal: "O ódio nega de início a liberdade do ser aborrecido, a muda para destino, transformando o sujeito em objeto, como faz a morte. De uma forma menos simbólica e mais realista, o ódio contesta ao ser odiado seu direito à existência. O ódio aprova o mundo ser esse campo fechado, essa natureza atéia onde triunfa a morte. Todo ódio é, no limite, ódio de Deus, possui a morte de Deus. O niilismo é a metafísica do ódio. 
ta identidade investe a forma de deformações agonizantes, configura um movimento de velar e desvelar sob o imperativo de uma linguagem que cultua a heresia. Tal oscilação pode ser observada, tomando-se como exemplo trechos que insistem no culto elevado da arte contrapostos a trechos em que o poeta reconhece a impossibilidade:

O que tu podes, só, é agarrar com frenesi ou com ódio a minha Obra dolorosa e solitária e lê-la e detestá-la e revirar-lhe as folhas, truncar-lhe as páginas, enodoar-lhe a castidade branca dos períodos, profanar-Ihe o tabernáculo da linguagem, riscar, traçar, assinalar, cortar com dísticos estigmatizantes, com lábeus obscenos, com golpes fundos de blasfêmia as violências da intensidade, dilacerar enfim toda a Obra, num ímpeto covarde de impotência ou de angústia.

Mas, para chegares a esse movimento apaixonado, dolorido, já eu antes terei, por certo - eu o sinto, eu o vejo! - te arremessado profundamente, abismantemente pelos cabelos a minha Obra e obrigado a tua atenção comatosa a acordar, a acender, a olfatar, a cheirar com febre, com delírio, com cio, cada adjetivo, cada verbo que eu faça chiar como um ferro em brasa no organismo da Idéia (... 32

Neste trecho, o sujeito lírico é aquele que crê na sua obra e no poder transformador da arte. A inscrição da força da arte nos espíritos estreitos dá-se como em um corpo: corta, golpeia, dilacera. E o sujeito profetiza a transformação que a arte acarretará. A relação estabelecida entre estética e crueldade, a arte que fisicamente desencadeia a dor, talvez sirva como prenúncio do movimento posterior, onde a percepção do impasse e da angústia toma o lugar do idealismo. É assim que a crença cede espaço à desolação e ao ódio, o artista ouve uma voz que vem de dentro de si - o duplo - a dizer-lhe:

- Tu és dos de Cam, maldito, réprobo, anatematizado! Falas em Abstrações, em Formas, em Espiritualidades, em Requintes, em Sonhos! Como se tu fosses das raças de ouro e da aurora, se viesses dos arianos, depurado por todas as civilizações, célula por célula, tecido por tecido (...)

Artista?! loucura! Loucura! Pode lá ser isso se tu vens dessa longínqua região desolada, lá do fundo exótico dessa África sugestiva, gemendo, Criação dolorosa e sanguino-

32 SOUSA, João da Cruz e, op. cit., p. 670. 
lenta de Satãs rebelados, dessa flagelada África, grotesca e triste, melancólica, gênese assombrosa de gemidos, tetricamente fulminada pelo banzo mortal; dessa África dos Suplícios, sobre cuja cabeça nirvanizada pelo desprezo do mundo Deus arrojou toda a peste letal e tenebrosa das maldições eternas! 33

Aqui, movimento inverso, o artista atinge o ápice do paroxismo, não reconhece a si mesmo, questiona sua identidade e alteridade. A voz deste duplo que fala ao poeta vem de dentro de si mesmo, prova de que as marcas do desconhecimento de si se oferecem do próprio mergulho na subjetividade esfacelada. À constituição da alteridade do artista negro que fala em nome de outros, é oferecida a razão da ciência, a força dos empirismos, o passado africano e a filiação ao trabalho. O negro, presença irrepresentável cuja natureza é considerada demoníaca dada a filiação à esfera da produção, comparece na teia da prosa através do concerto inquietante de suas vozes interiores.

O "Emparedado" é texto que evidencia o coroamento do processo de impasse da constituição da alteridade, culminando com o soterramento das vozes que o sujeito pretendia encarnar. A percepção da inexorabilidade deste processo entrelaça-se, sob a forma do auto-flagelo, em uma espécie de valorização do eu às avessas. De modo perverso, daquele que toma para si o mal e sente a volúpia da queda no abismo, o poeta erige a dor como meio de redenção. O paroxismo de seu martírio entrevê a morte na sua dupla natureza de volúpia e aniquilamento.

| Simone Rossinetti Rufinoni é doutoranda em Literatura Brasileira na Universidade de São Paulo. 